\title{
High Hydrogen Ion Concentration Causes a Blue Shift in Gold Nanoparticles
}

\author{
Po-Yen Lin, Po-Chen Lin and Chien-Jung Huang *
}

check for

updates

Citation: Lin, P.-Y.; Lin, P.-C.; Huang, C.-J. High Hydrogen Ion Concentration Causes a Blue Shift in Gold Nanoparticles. Crystals 2021, 11, 132. https://doi.org/10.3390/ cryst11020132

Academic Editor: Rajratan Basu

Received: 7 January 2021

Accepted: 24 January 2021

Published: 28 January 2021

Publisher's Note: MDPI stays neutral with regard to jurisdictional claims in published maps and institutional affiliations.

Copyright: (c) 2021 by the authors. Licensee MDPI, Basel, Switzerland. This article is an open access article distributed under the terms and conditions of the Creative Commons Attribution (CC BY) license (https:/ / creativecommons.org/licenses/by/ $4.0 /)$.
Department of Applied Physics, National University of Kaohsiung, Kaohsiung 81148, Taiwan; linpoyen8808@gmail.com (P.-Y.L.); s6993975@gmail.com (P.-C.L.)

* Correspondence: chien@nuk.edu.tw

\begin{abstract}
In this research, our team used a rare electrochemical method to obtain gold nanoparticles (GNPs). The growth solution has been added with nitric acid in order to observe the effect of GNPs. The solution also included cetyltrimethylammonium bromide (CTAB) and acetone. All reactions involved the oxidation of acetone and chain polymerization. Therefore, the GNPs changed to a su pramolecular structure. In addition, our team measured absorption wavelength via ultraviolet/ visible spectrophotometer and found an obviously blue shift. This short absorption wavelength is obviously different from other GNPs.
\end{abstract}

Keywords: electrochemical; gold nanoparticles; chain polymerization; blue shift

\section{Introduction}

In the past decade, nanotechnology has been extensively studied because of the unique characteristics of nanoparticles. Due to the quantum size effect, nanoparticles have many unique characteristics when they are smaller than a certain size. This study focuses on gold nanoparticles (GNPs). The studies on gold nanoparticles are the most abundant in the current literature [1-8], mainly because of the wide range of applications of such nanoparticles. Gold has unique physical and chemical properties, such as small size, large surface area and mass ratio, fluorescence [8,9], surface plasmon resonance (SPR) effect [2-5], surface-enhanced Raman scattering [10], and electrochemistry. After the GNPs' surface is specially labeled, it can be used to bond with small molecules to expand the application of GNPs and can be used in biomedical research and clinical applications [11,12].

The manufacturing methods of GNPs are very diverse, including the laser ablation method [13], metal vapor synthesis, the chemical reduction method, and the electrochemical method [14]. The most commonly used method is chemical reduction. In this study, the researchers used a rare electrochemical method. In 1994, Reetz, M.T. and Helbig, W. [14] demonstrated the use of electrochemical methods to generate certain metal nanoparticles. The particle size can be adjusted simply by controlling the current or voltage of the electrolysis device. When electrolysis is performed electrochemically, the bulk metal of the anode is oxidized and produces metal ions; these metal ions will migrate to the cathode, and then the cathode will perform reduction and finally form atoms on the surface of the cathode. These atoms will be coated with a surfactant to form nanoparticles. The surfactant in the growth solution acts like an electrolyte and a stabilizer. The molecules that interact with each other will gather to form a micelle template to control the size and shape of the nanoparticles $[15,16]$. Therefore, the surfactant plays an important role. In addition, when an organic solvent is added to the surfactant solution, the organic solvent can usually decompose the polar group of the microcell at the interface of water and hydrocarbon so that the organic solvent will reduce the surface of the ionic micelles. The charge density changes the geometry of the surfactant cell template $[17,18]$. Therefore, adding organic solvent acetone during the electrolysis process may cause changes in the shape of the microcell template [19-22]. In this study, the research team developed various types of 
nanoparticles using this method [19-23]. This study mainly explores the effect of strong acids on gold nanoparticles. In the experiment, acetone is added as an organic solvent; the surfactant is cetyltrimethylammonium bromide (CTAB). Surfactant molecules align to form an electric bilayer on the surface of GNPs. The thickness of this electric bilayer will affect the electrostatic force between the particles. A proper thickness can stabilize the entire environment. The strong acid used is nitric acid. The final result will consider the absorption spectrum, full width at half maximum (FWHM), solution color, particle size, and shape.

As gold has good biological compatibility and the nano-gold surface has special effects (easy to bind with sulfur- and hydrogen-based components), nano-gold is often used in biomedical detection, disease diagnosis, and genetic detection. GNPs can also be applied to solar cells to improve conversion efficiency through doping. This study expects that short-wavelength GNPs can make a greater contribution to solar cells.

\section{Experimental Process and Method}

\subsection{Material}

(a) The growth solution of $0.08 \mathrm{M}$ was prepared by powder species: cetyltrimethylammonium bromide (CTAB, Fluka, 98\%), liquid species:deionized water (DI water, 18.2 $\mathrm{M} \Omega$ ) of $3 \mathrm{~mL}$, acetone $\left(\mathrm{CH}_{3} \mathrm{COCH}_{3}\right.$, J. T. Baker), and nitric acid $\left(\mathrm{HNO}_{3}\right.$, Fluka) of 30, 50, 70, and $90 \mu \mathrm{L}$ in test tubes.

(b) Aqua regia (nitric acid hydrochloride) solution was prepared by nitric acid $\left(\mathrm{HNO}_{3}\right.$, Honeywell Fluka) and hydrochloric acid $(\mathrm{HCl}, \mathrm{J}$. T. Baker, 37\%) at the volume ratio of 1:3.

(c) Electrochemical synthesis with two electrodes consisting of gold plate $(\mathrm{Au}, 99 \%)$ and platinum plate $(\mathrm{Pt}, 99 \%)$, connected with solid conductors (copper wire, $99 \%$ ) to a complete electrolyzer system. A power supply (Agilent E3647A) offered a steady operating current through a fixed depth of electrode below the liquid level $(8 \mathrm{~mm})$. The detailed information of each material is also listed in Table 1.

Table 1. Detailed information on the materials.

\begin{tabular}{ccc}
\hline Item & Value & Unit \\
\hline Au plate & $30 \times 10 \times 0.5$ & $\mathrm{~mm}^{3}$ \\
\hline Pt plate & $30 \times 10 \times 0.5$ & $\mathrm{~mm}^{3}$ \\
\hline CTAB powder $(0.08 \mathrm{M})$ & 87.5 & $\mathrm{mg}$ \\
\hline DI water & 18.2 & $\mathrm{M} \Omega$ \\
\hline Acetone & 500 & $\mu \mathrm{L}$ \\
\hline $\mathrm{HNO}_{3}$ & $30 / 50 / 70 / 90$ & $\mu \mathrm{L}$ \\
\hline Aqua regia $\left(\mathrm{HNO}_{3}\right.$ per $\left.\mathrm{HCl}\right)$ & $1: 3$ & volume \\
\hline
\end{tabular}

\subsection{Synthesis of GNPS}

(a) Both $\mathrm{Au}$ and Pt were cut into appropriate pieces $\left(30 \times 10 \times 0.5 \mathrm{~mm}^{3}\right)$ to act as anode and cathode, respectively. After standard cleaning operation, including polishing with fine sandpaper, immersing in aqua regia solution, and washing in DI water for $5 \mathrm{~min}$ each, these two electrodes were dried with nitrogen gas, positioned $5 \mathrm{~mm}$ apart, and secured using Teflon spacers.

(b) Afterwards, a test tube containing growth solution was immersed in an ultrasonic oscillator (Hwashin, Model 420) at $40 \mathrm{KHz}$ for $5 \mathrm{~min}$, and the water temperature was kept at $24 \pm 1{ }^{\circ} \mathrm{C}$. The electric voltage between two electrodes was set at $2.5 \mathrm{~V}$, and the test tube was electrolyzed and oscillated in the ultrasonic oscillator at $5 \mathrm{~mA}$ for $5 \mathrm{~min}$. The complete process of electrochemical synthesis lasted $5 \mathrm{~min}$, and each parameter is listed in Table 2. 
(c) The GNPs in powder form can be obtained using the following steps: (i) After adding toluene into the product solution and centrifuging at 12,000 rpm for $30 \mathrm{~min}$, the interface separation (GNPs, toluene, and surfactant, from bottom to top) is accomplished; (ii) nanoparticles can be acquired through drying in an electric oven at $100{ }^{\circ} \mathrm{C}$ for three days, after extracting the CTAB solution that forms as a surfactant in the interlayer.

Table 2. Parameters for sonoelectrochemistry fabrication.

\begin{tabular}{ccc}
\hline Parameter & Value & Unit \\
\hline Depth of electrode below the liquid level & 8 & $\mathrm{~mm}$ \\
\hline Oscillated frequency & 40 & $\mathrm{KHz}$ \\
\hline Oscillated temperature & $24 \pm 1$ & ${ }^{\circ} \mathrm{C}$ \\
\hline Operated current & 5 & $\mathrm{~mA}$ \\
\hline Oscillated and operated time & 5 & $\mathrm{~min}$ \\
\hline
\end{tabular}

\subsection{Measurement and Calculation of GNPs' Characteristics}

The optical performance of the GNP sample, filled with DI water in a quartz tube of $12.5 \times 12.5 \times 45 \mathrm{~mm}^{3}$, was measured by ultraviolet/visible (UV-vis) spectroscopy (HITACHI, U-3900) in the spectral region from 350 to $850 \mathrm{~nm}$. The analysis of microstructure morphology was observed by analytical scanning transmission electron microscopy (TEM, JEM-3010, JEOL) at an accelerating voltage of $200 \mathrm{kV}$. The composition of GNPs can also be obtained by energy-dispersive X-ray spectroscopy (EDS). Through the three steps: mixing, centrifugation, and baking, the TEM sample of GNPs can be obtained. The mixing solution obtained by adding DI water or toluene was centrifuged to extract the hierarchical CTAB solution. Before placing it on standard copper grids (formvar carbon-supported film), with drying in an electric oven at $100{ }^{\circ} \mathrm{C}$, centrifugation and extraction need to be repeated three times.

\section{Result and Discussion}

As shown in Figure 1, gold nanoparticles were prepared by a two-electrode electrochemical system. In the process, the gold sheet, as the anode, was electrolyzed, and then, the produced ions were reduced to atoms through free radicals generated by oscillation, following four main Equations [14]:

$$
\begin{gathered}
\mathrm{H}_{2} \mathrm{O} \rightarrow \mathrm{H}^{+}+\mathrm{OH}^{-} \text {(sonolysis) } \\
\mathrm{OH}^{+}+\mathrm{RH}^{-} \rightarrow \mathrm{R}^{+}+\mathrm{H}_{2} \mathrm{O} \\
\mathrm{RH} \rightarrow \mathrm{R}+\mathrm{H} \text { (sonolysis) } \\
\mathrm{R}+\mathrm{Au}^{\mathrm{m}+} \rightarrow \mathrm{Au}^{\mathrm{m}-1}+\mathrm{H}^{+}+\mathrm{R}
\end{gathered}
$$

In Equation (1), the bonding of water molecules in the growth solution will be broken by oscillation to produce hydrogen $(\mathrm{H})$ and hydroxyl $(\mathrm{OH})$ ions. These two ions react with a hydrocarbon $(\mathrm{RH})$ to produce the free radical $\left(\mathrm{R}^{+}\right)$in Equation (2). The RH generates free radicals under the action of oscillation in Equation (3). Free radicals can reduce the gold ions generated at the gold electrode from one to three valences and then to gold atoms in Equation (4). Eventually, it will move to the cathode to produce gold nanoparticles. To stabilize the entire system, the researchers added the stabilizer CTAB in the growth solution. This is a surfactant. When the critical microcell concentration is reached, it begins to form microcells and coat the gold atoms. Finally, stable gold nanoparticles will be produced. The experimental system is shown in Figure 1. Next, the optical property is discussed. 


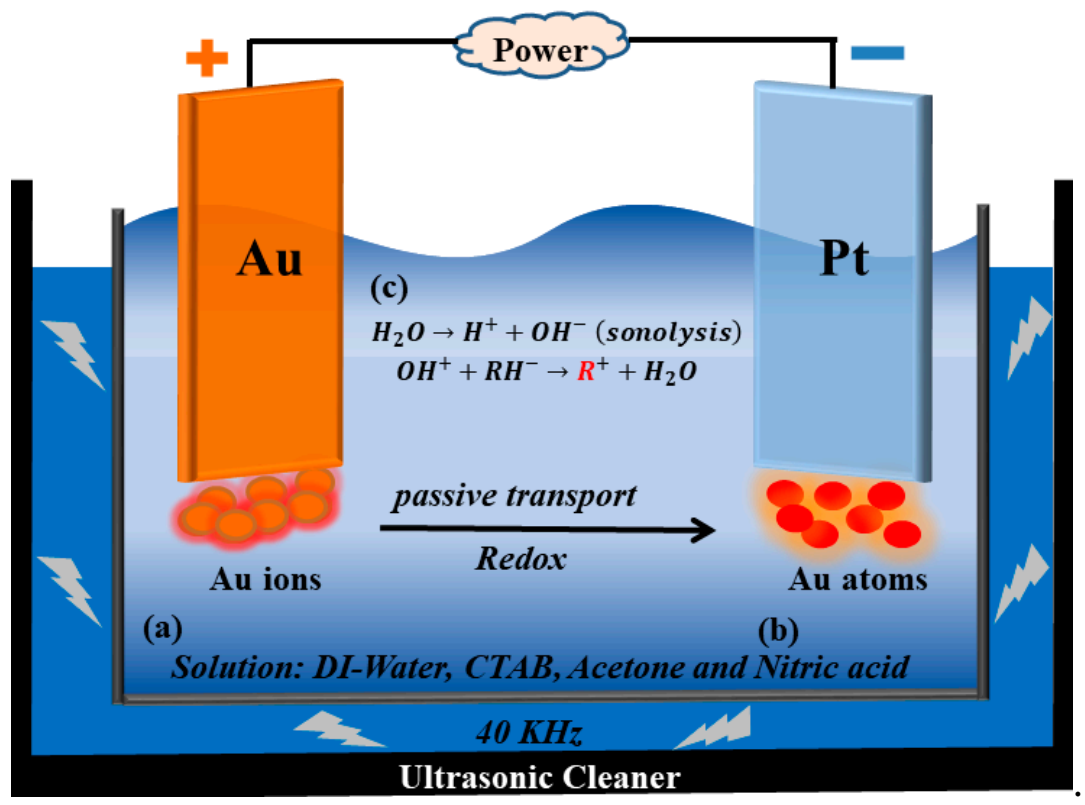

Figure 1. Schematic diagrams for gold nanoparticles (GNPs) via electrochemistry preparation: (a) the preparation of grown solution; (b) $\mathrm{HNO}_{3}$ added as a catalyst, forming a micelle template of condensation reaction; (c) electrolysis and oscillation are kept working in the interim.

As shown in Figure 2, the absorption spectrum of GNPs obtained by different additions of $\mathrm{HNO}_{3}(30,50,70$, and $90 \mu \mathrm{L})$ was measured from 350 to $500 \mathrm{~nm}$ to gain the optical properties. The absorbed peak of GNPs is located at $398 \mathrm{~nm}$. The intensity is obviously increased with the increased addition of $\mathrm{HNO}_{3}$; the highest intensity is achieved with the $\mathrm{HNO}_{3}$ addition of $70 \mu \mathrm{L}$. According to our previous research [19-23], it was clearly found that a huge blue shift phenomenon, from 528 to $398 \mathrm{~nm}$, was accomplished unprecedently. The reason for the large blue shift is attributed to the supramolecular structure of oxidation between acetone and $\mathrm{HNO}_{3}$ [24-26]. Generally, the variation in GNP size causes the blue or red shift, leading to a short shift distance of 10-15 nm. Compared to other groups [19-23], the blue shift difference of $130 \mathrm{~nm}$ is quite unique and large in this study.

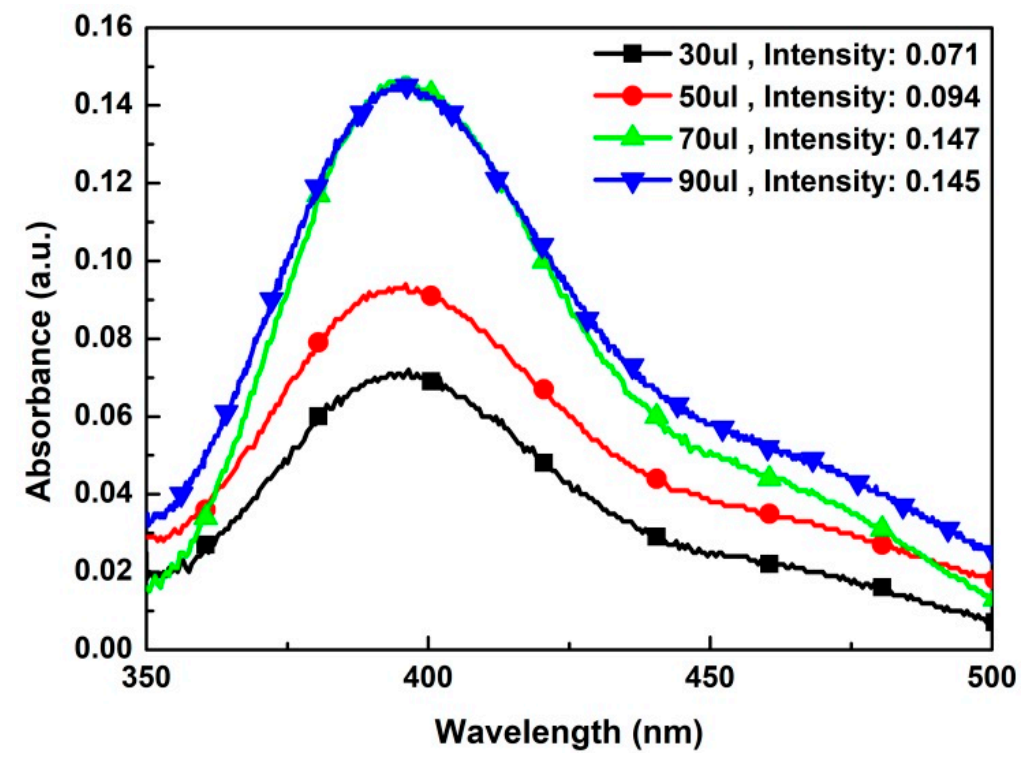

Figure 2. Light absorbance spectra of GNP solutions obtained at different $\mathrm{HNO}_{3}$ additions of 30, 50, 70 , and $90 \mu \mathrm{L}$ within a growth solution. 
Absorption intensity generally involves the uniformity and average particle size of the overall particles. Basically, we can evaluate the uniformity of the overall GNPs by calculating the value of FWHM. Figure 3 shows the FWHM of different additions of $\mathrm{HNO}_{3}$ $(30,50,70$, and $90 \mu \mathrm{L})$. It is found that the FWHM presented under different amounts of $\mathrm{HNO}_{3}$ is similar; the lowest value was obtained at $70 \mu \mathrm{L} \mathrm{HNO}$, that is to say, the uniformity obtained when adding $70 \mu \mathrm{L}$ is the best. Figure 3 also shows the average particle size of the GNPs produced by $\mathrm{HNO}_{3}$ under different amounts. When $\mathrm{HNO}_{3}$ is initially added, there is a significant decrease in particle size, which indicates that the particle size is suppressed after the addition of $\mathrm{HNO}_{3}$. When we added $70 \mu \mathrm{L}$ of $\mathrm{HNO}_{3}$, we get the GNPs with the smallest particle size.

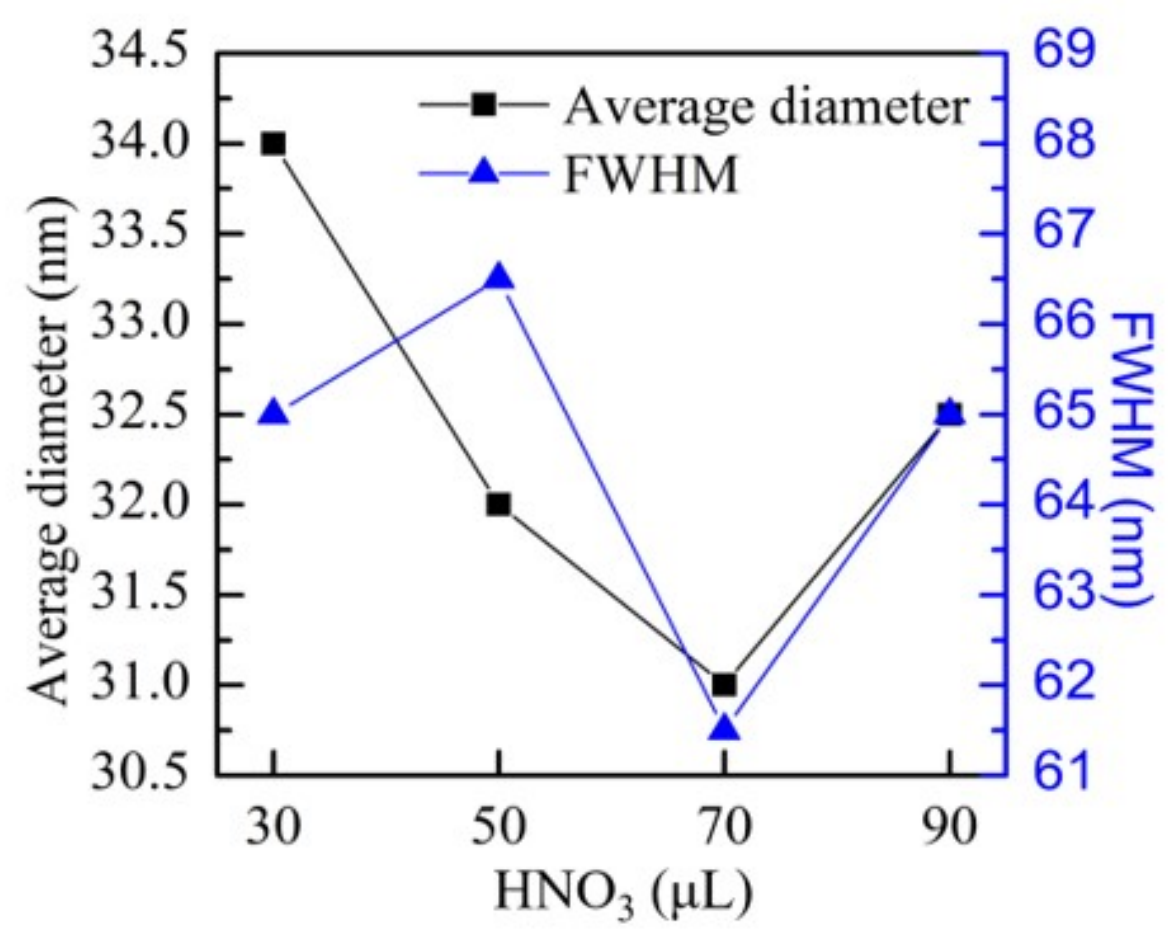

Figure 3. Average diameter and full width at half maximum (FWHM) of GNP solutions obtained at different $\mathrm{HNO}_{3}$ additions of 30, 50, 70, and $90 \mu \mathrm{L}$ within a growth solution.

Figure 4 shows the TEM images of different amounts of $\mathrm{HNO}_{3}$. GNPs with small particle size are shown in the $30 \mu \mathrm{L}$ figure, and it was found that there are aggregation conditions; 70 and $90 \mu \mathrm{L}$ amounts of $\mathrm{HNO}_{3}$ are aggregated into an island structure. This may be one of the reasons for the decrease in absorption strength. In addition, a shell-like substance was found in the $30 \mu \mathrm{L}$ figure; thus, EDS was used for analysis.

Figure 5 shows the EDS analysis results of a specific area of the $30 \mu \mathrm{L}$ sample. In this analysis, because the added nitric acid contains nitrogen, gold and nitrogen are selected to analyze the results. The results are displayed in places with more shell-like materials (green squares); the main element distribution is nitrogen. The material in the red square is mainly the aggregation of gold. Therefore, it is reasonable to speculate that nitrogen-related compounds generate and coat GNPs. Figure 6 shows that the irregular GNPs formed by the aggregation of particles are caused by numerous particles that are combined. The boundaries of these particles have different directions, resulting in defects. The reason for the aggregation may be due to the chain polymerization reaction. The chain polymerization reaction between acetone and nitric acid has been described in other studies. The initial step of acetone oxidation can be to extract $\mathrm{H}$ atoms from the methyl group of the ketone form of acetone by $\mathrm{HNO}_{3}$ molecules or to add $\mathrm{HNO}_{3}$ molecules to the double bond in the enol form of acetone, and then reduce nitric acid to nitrous acid. The equilibrium 
shifts from $\mathrm{NO}_{2}$ to $\mathrm{N}_{2} \mathrm{O}_{3}$, then to $\mathrm{HNO}_{2}$, and, finally, to $\mathrm{NO}_{2}{ }^{-}$, according to the following equations [24-26]:

$$
\begin{gathered}
\mathrm{CH}_{3} \mathrm{C}(\mathrm{O}) \mathrm{CH}_{3}+\mathrm{HNO}_{3} \rightarrow \mathrm{CH}_{3} \mathrm{C}(\mathrm{O}) \dot{\mathrm{CH}}_{2}+\mathrm{H}_{2} \mathrm{O}+\mathrm{NO}_{2} \\
3 \mathrm{NO}_{2}+\mathrm{H}_{2} \mathrm{O} \leftrightarrow \mathrm{NO}+2 \mathrm{HNO}_{3} \\
\mathrm{NO}+\mathrm{NO}_{2} \leftrightarrow \mathrm{N}_{2} \mathrm{O}_{3} \\
\mathrm{~N}_{2} \mathrm{O}_{3}+\mathrm{H}_{2} \mathrm{O} \leftrightarrow 2 \mathrm{HNO}_{2} \\
\mathrm{HNO}_{2}+\mathrm{H}_{2} \mathrm{O} \leftrightarrow \mathrm{H}_{3} \mathrm{O}^{+}+\mathrm{NO}_{2}^{-}
\end{gathered}
$$

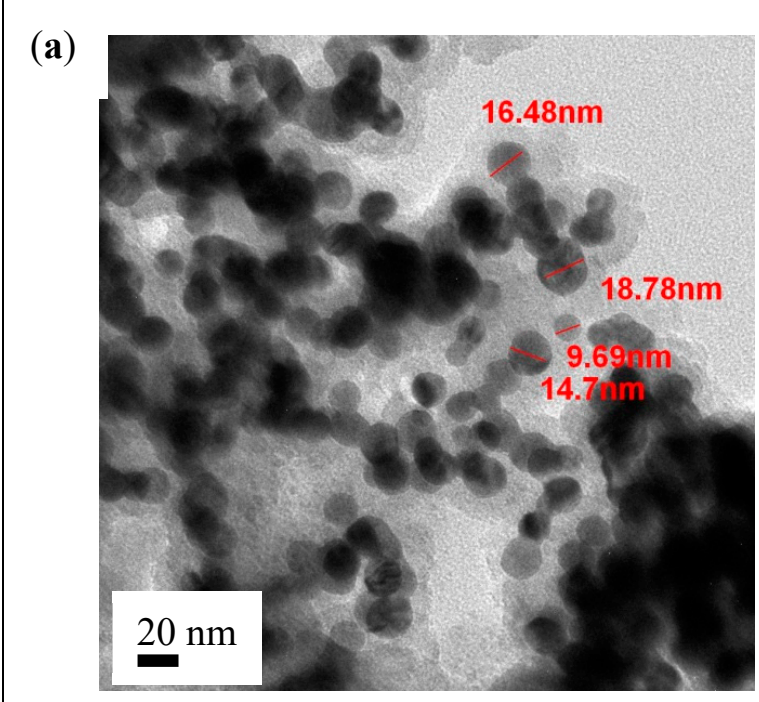

(b)

(d)

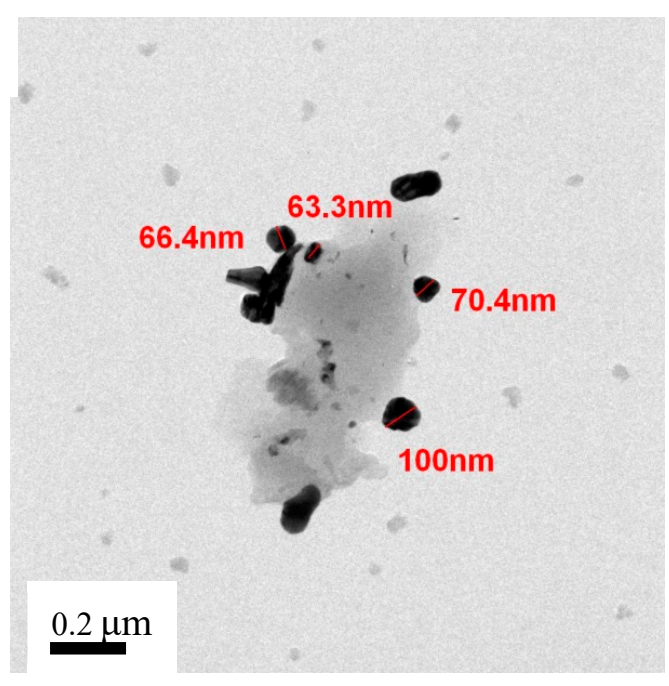

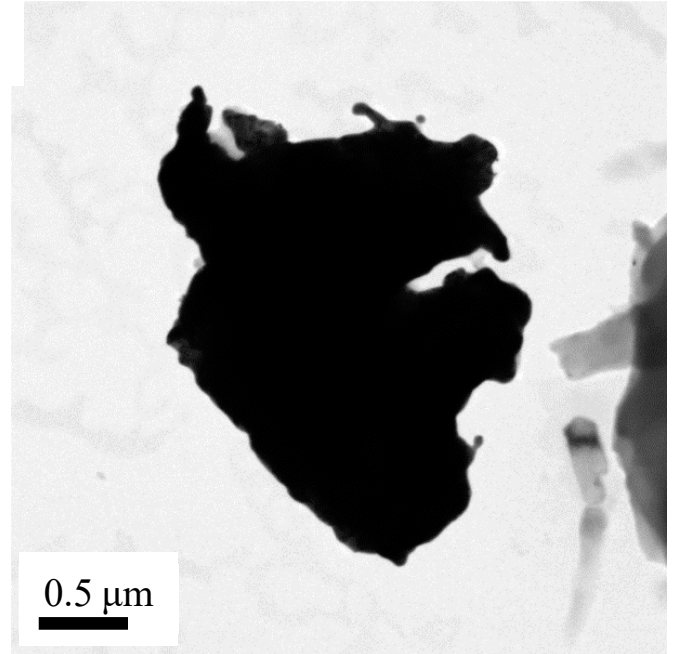

(c)

Figure 4. Growth solution is added to (a) 30, (b) 50, (c) 70, and (d) $90 \mu \mathrm{L} \mathrm{HNO}_{3}$ solution. 


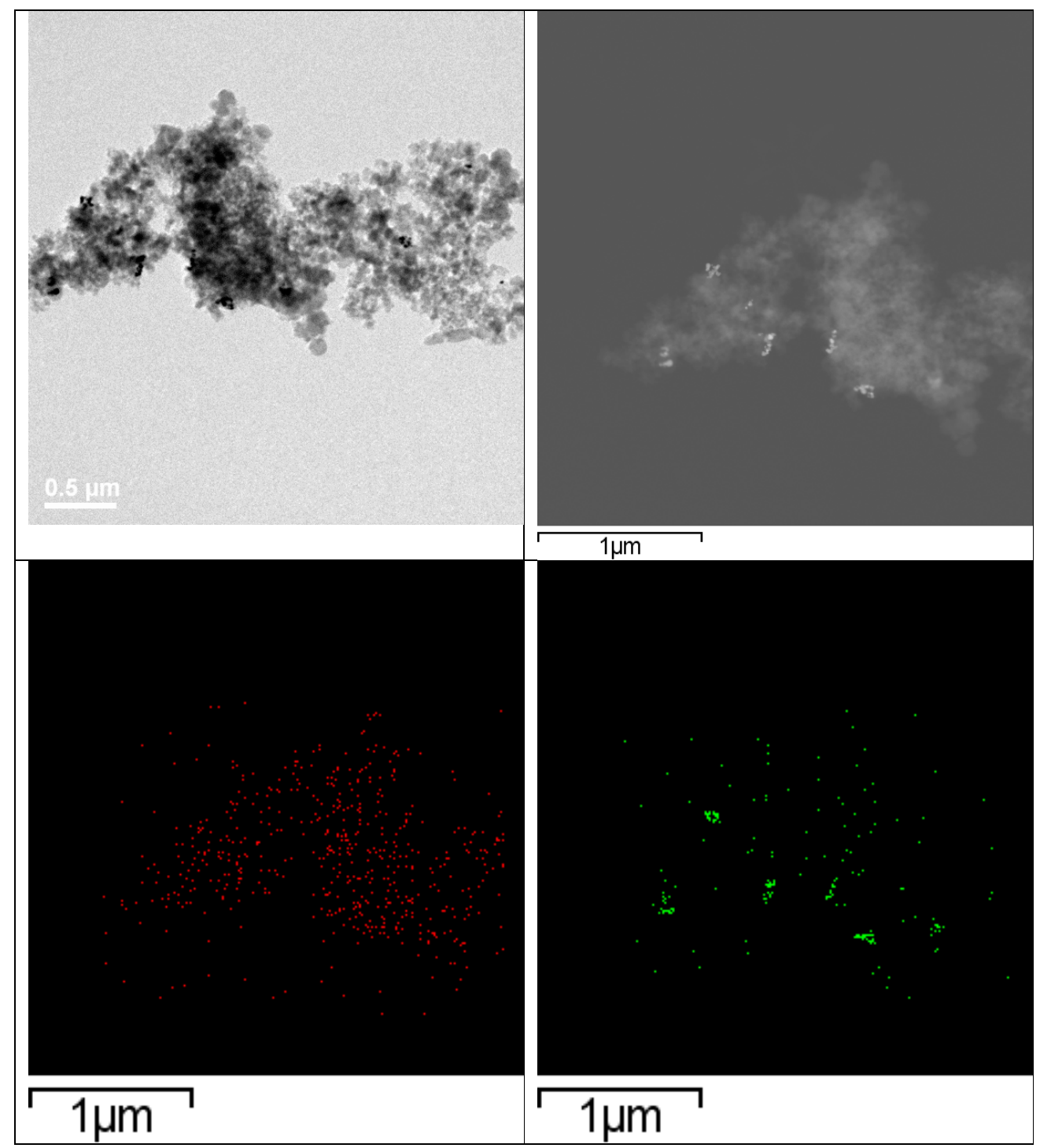

Figure 5. Energy-dispersive X-ray spectroscopy (EDS) analysis of GNP solutions was obtained with an $\mathrm{HNO}_{3}$ addition of $30 \mu \mathrm{L}$ within a growth solution (Sample A). In addition, red and green square represent the distribution of nitrogen and gold, respectively.

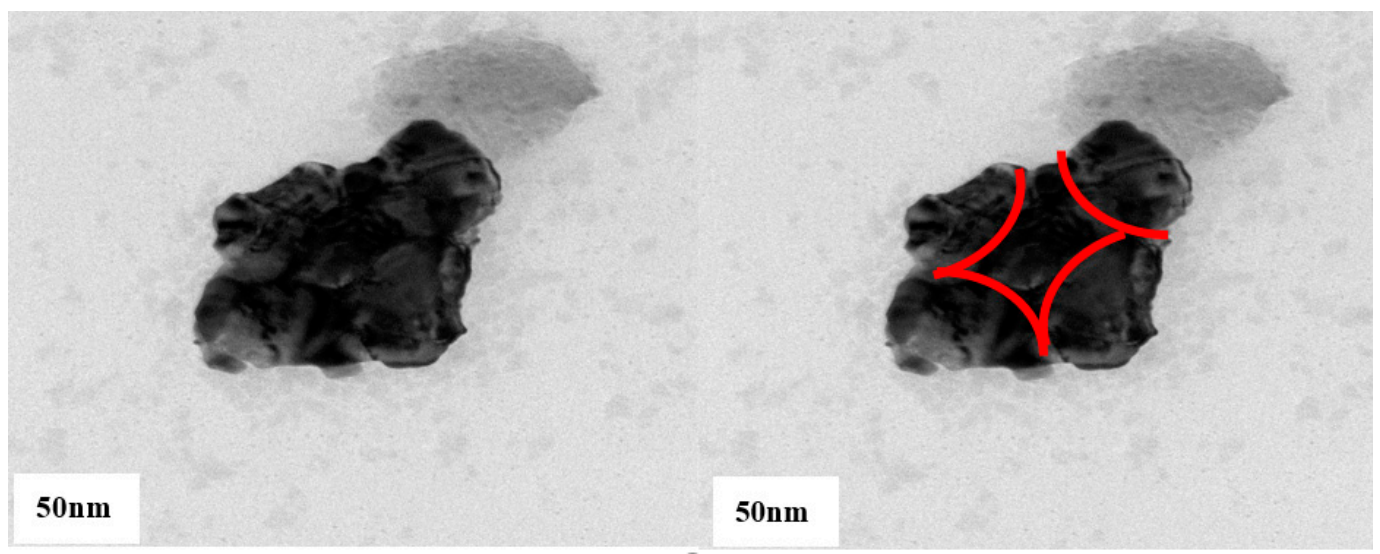

(a)

(b)

Figure 6. (a) Transmission electron microscopy (TEM) analysis of GNPs observed a defect in Sample D. (b) TEM analysis of GNPs observed many GNPs were combined with large GNPs by the chain polymerization reaction. 
With the development of the process, these reduced nitrogen-containing molecules appear in the system. When the Equations (6)-(9) moves to the left, $\mathrm{NO}_{2}$ is formed, and these reactions lead to chain branching. The following describes the chain polymerization reaction [24-26], which consumes $\mathrm{NO}_{2}$ to form acetone oxidation products.

$$
\begin{gathered}
\mathrm{CH}_{3} \mathrm{C}(\mathrm{O}) \mathrm{CH}_{3}+\mathrm{NO}_{2} \rightarrow \mathrm{CH}_{3} \mathrm{C}(\mathrm{O}) \dot{\mathrm{CH}}_{2}+\mathrm{HNO}_{2} \\
\mathrm{CH}_{3} \mathrm{C}(\mathrm{O}) \dot{\mathrm{C}} \mathrm{H}_{2}+\mathrm{NO}_{2} \rightarrow \mathrm{CH}_{3} \mathrm{C}(\mathrm{O}) \mathrm{CH}_{2} \mathrm{O}+\mathrm{NO} \\
\mathrm{CH}_{3} \mathrm{C}(\mathrm{O}) \mathrm{CH}_{2} \mathrm{O} \rightarrow \mathrm{CH}_{3} \dot{\mathrm{C}}(\mathrm{O})+\mathrm{CH}_{2} \mathrm{O} \\
\mathrm{CH}_{3} \dot{\mathrm{C}}(\mathrm{O})+\mathrm{NO}_{2} \rightarrow \mathrm{CH}_{3} \mathrm{C}(\mathrm{O}) \mathrm{ONO} \\
\mathrm{CH}_{3} \mathrm{C}(\mathrm{O}) \mathrm{ONO}+\mathrm{H}_{2} \mathrm{O} \rightarrow \mathrm{CH}_{3} \mathrm{COOH}+\mathrm{HNO}_{2} \\
\mathrm{CH}_{2} \mathrm{O}+\mathrm{NO}_{2} \rightarrow \dot{\mathrm{C}} \mathrm{HO}+\mathrm{HNO}_{2}
\end{gathered}
$$

With the acid-base equilibrium in Reaction (5), the $\mathrm{NO}_{2}$ concentration in the process will increase. For the two $\mathrm{NO}_{2}$ molecules consumed in Reactions (10) and (11), three $\mathrm{NO}_{2}$ molecules were regenerated by balancing (5). The formed $\mathrm{NO}_{2}$ molecules can enter the oxidation reaction again to form $\mathrm{NO}$ and $\mathrm{HNO}_{2}$. This process can be formally regarded as a branched-chain reaction. The above reproducible reactions will form supramolecular structures (Figure 7). For detailed principles and proofs, please refer to other literature.

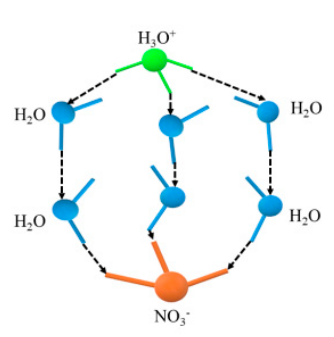

(a)

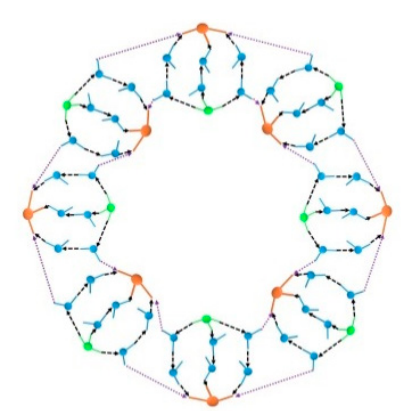

(b)

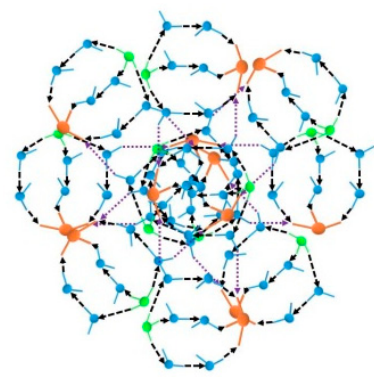

(c)

Figure 7. The growth process module of the supramolecular structure $(\mathbf{a}) \rightarrow(\mathbf{b}) \rightarrow(\mathbf{c})$, produced in the reaction of acetone and nitric acid. (a) Initial structure generation. (b) chain polymerization reaction starts. (c) The chain polymerization reaction ends and becomes a supramolecular structure.

As there are a large number of free radicals in the chain polymerization reaction, it indirectly affects the reduction and growth of GNPs. Therefore, it is speculated that gold ions cannot be successfully reduced. The GNPs in this experiment will likely exist in the form of monovalent (colorless), trivalent (light yellow), or atomic (Figure 8a) nanoparticles. The nitrogen compound produced by the final reaction of acetone and nitric acid is basically red or colorless. The final product made in this experiment is light yellow (Figure 8b), which can be speculated to be the form of trivalent gold. Therefore, the addition of nitric acid not only hinders the reduction of gold but also suppresses the particle size. In addition, for nitrogen compounds, including nitric acid, nitrate, and nitrite, the absorption wavelength is about $350 \sim 450 \mathrm{~nm}$, which is the main reason for the blue shift. 
(c)
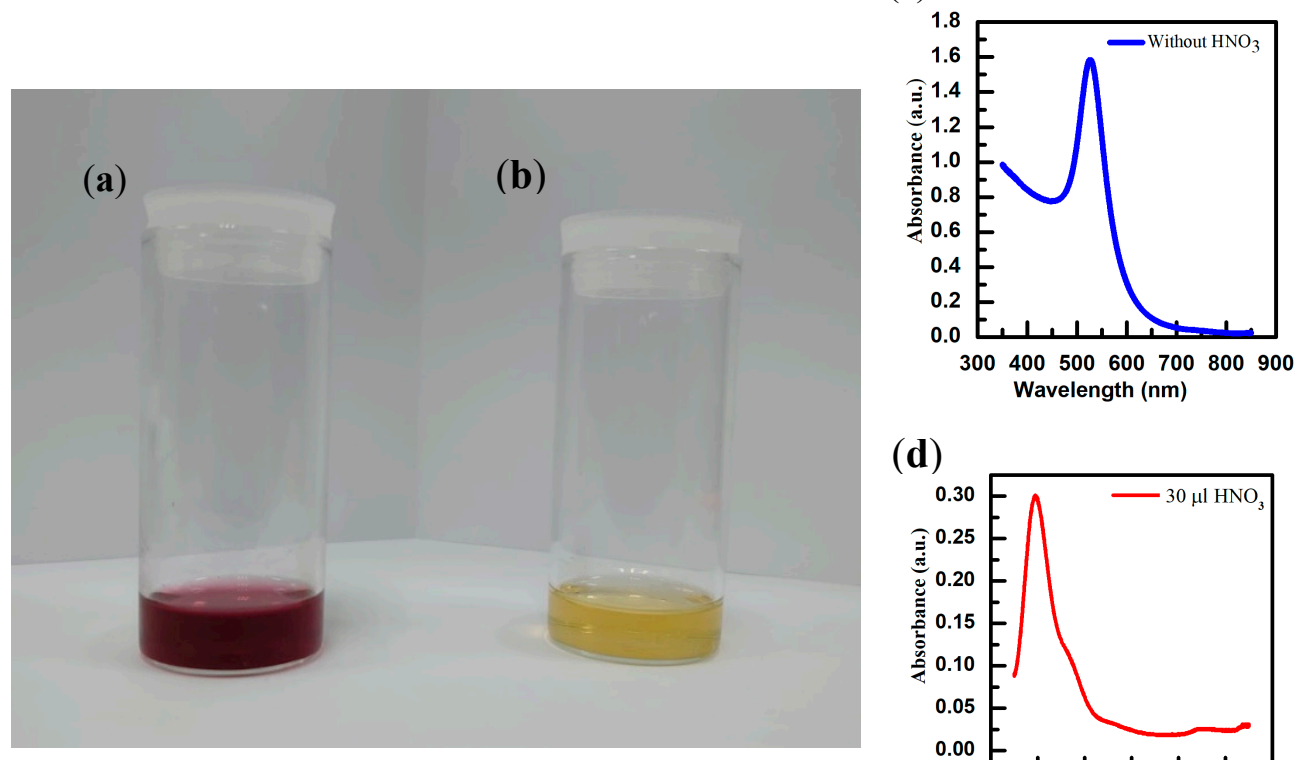

(d)

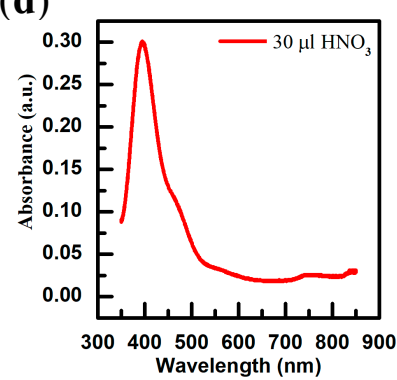

Figure 8. The growth solution with and without nitric acid. (a) The growth solution color without nitric acid. (b) The growth solution color with nitric acid. (c) The absorption wavelength without nitric acid. (d) The absorption wavelength with $30 \mu \mathrm{L}$ nitric acid.

\section{Conclusions}

In this study, a breakthrough was successfully made for the electrochemical manufacture of gold nanoparticles. A large blue shift is a very rare result. This result may be caused by the change of the dielectric constant around the GNPs, which will directly affect the change in the absorption wavelength of the SPR effect. Although the absorption strength is insufficient, it can be further improved, and stable manufacturing methods and formulations can be found in the future. Here, we only need a moderate amount $(70 \mu \mathrm{L})$ to get the best result. In addition, it also explains the phenomenon of agglomeration, which is mainly related to acetone, nitric acid, and free radicals. It has a chain growth effect and grows into a supramolecular structure. It may be used in thin films and solar cells in the future. Macromolecular GNPs can enhance the scattering and optical path. In the use of small molecules, if absorption intensity is improved, this phenomenon can be used in the absorption layer, absorbing the short wavelength; combining with other materials will help form a large range of absorption wavelength solar cells. The application of this material is very promising.

Author Contributions: Data curation, P.-Y.L.; Formal analysis, P.-Y.L.; Funding acquisition, C.-J.H.; Investigation, P.-Y.L.; Resources, P.-C.L.; Writing-original draft, P.-Y.L.; Writing-review \& editing, C.-J.H. All authors have read and agreed to the published version of the manuscript.

Funding: This work is sponsored by the Ministry of Science and Technology (MOST) of the Republic of China under contact number of 108-2221-E-390-006.

Institutional Review Board Statement: Not applicable.

Informed Consent Statement: Not applicable.

Data Availability Statement: Not applicable.

Acknowledgments: In here: thanks the contribution and guide in this paper for Shui-Yang Lien. Besides, this work is sponsored by the Ministry of Science and Technology (MOST) of the Republic of China under contact number 108-2221-E-390-006.

Conflicts of Interest: The authors declare no conflict of interest. 


\section{References}

1. Lucky, S.S.; Soo, K.C.; Zhang, Y. Nanoparticles in Photodynamic Therapy. Chem. Rev. 2015, 115, 1990-2042. [CrossRef] [PubMed]

2. Ariga, K.; Li, J.; Fei, J.; Ji, Q.; Hill, J.P. Nanoarchitectonics for Dynamic Functional Materials from Atomic-/Molecular-Level Manipulation to Macroscopic Action. Adv. Mater. 2016, 28, 1251-1286. [CrossRef] [PubMed]

3. Malgras, V.; Ji, Q.; Kamachi, Y.; Mori, T.; Shieh, F.-K.; Wu, K.C.-W.; Ariga, K.; Yamauchi, Y. Templated Synthesis for Nanoarchitectured Porous Materials. Bull. Chem. Soc. Jpn. 2015, 88, 1171-1200. [CrossRef]

4. Wolfbeis, O.S. An overview of nanoparticles commonly used in fluorescent bioimaging. Chem. Soc. Rev. 2015, $44,4743-4768$. [CrossRef]

5. Rubio, A.S. Modified Au-Based Nanomaterials Studied by Surface Plasmon Resonance Spectroscopy; Springer: Berlin, Germany, 2015.

6. Linic, S.; Aslam, U.; Boerigter, C.; Morabito, M. Photochemical transformations on plasmonic metal nanoparticles. Nat. Mater. 2015, 14, 567-576. [CrossRef] [PubMed]

7. Li, C.C.; Cai, W.; Cao, B.Q.; Sun, F.Q.; Li, Y.; Kan, C.X.; Zhang, L.D. Mass Synthesis of Large, Single-Crystal Au Nanosheets Based on a Polyol Process. Adv. Funct. Mater. 2006, 16, 83-90. [CrossRef]

8. Vilchis-Nestor, A.; Sánchez-Mendieta, V.; Camacho-López, M.A.; Gómez-Espinosa, R.M.; Camacho-López, M.A.; Arenas-Alatorre, J.A. Solventless synthesis and optical properties of Au and Ag nanoparticles using Camellia sinensis extract. Mater. Lett. 2008, 62, 3103-3105. [CrossRef]

9. Medley, C.D.; Smith, J.E.; Tang, Z.; Wu, Y.; Bamrungsap, S.; Tan, W. Gold Nanoparticle-Based Colorimetric Assay for the Direct Detection of Cancerous Cells. Anal. Chem. 2008, 80, 1067-1072. [CrossRef]

10. Jain, P.K.; Lee, K.S.; El-Sayed, I.H.; El-Sayed, M.A. Calculated Absorption and Scattering Properties of Gold Nanoparticles of Different Size, Shape, and Composition: Applications in Biological Imaging and Biomedicine. J. Phys. Chem. B 2006, 110, 7238-7248. [CrossRef]

11. Mizukoshi, Y.; Okitsu, K.; Maeda, Y.; Yamamoto, T.A.; Oshima, R.; Nagata, Y. Sonochemical preparation of bimetallic nanoparticles of gold/palladium in aqueous solution. J. Phys. Chem. B 1997, 101, 7033-7037. [CrossRef]

12. Daniel, M.-C.; Astruc, D. Gold nanoparticles: Assembly, supramolecular chemistry, quantum-size-related properties, and applications toward biology, catalysis, and nanotechnology. Chem. Rev. 2004, 104, 293-346. [CrossRef] [PubMed]

13. Kawasaki, M.; Masuda, K. Laser fragmentation of water-suspended gold flakes via spherical submicroparticles to fine nanoparticles. J. Phys. Chem. B 2005, 109, 9379-9388. [CrossRef] [PubMed]

14. Reetz, M.T.; Helbig, W. Size-Selective Synthesis of Nanostructured Transition Metal Clusters. J. Am. Chem. Soc. 1994, 116, 7401-7402. [CrossRef]

15. Kim, F.; Sohn, K.; Wu, J.; Huang, J. Chemical Synthesis of Gold Nanowires in Acidic Solutions. J. Am. Chem. Soc. 2008, 130, 14442-14443. [CrossRef] [PubMed]

16. Törnblom, M.; Henriksson, U. Effect of Solubilization of Aliphatic Hydrocarbons on Size and Shape of Rodlike C16TABr Micelles Studied by2H NMR Relaxation. J. Phys. Chem. B 1997, 101, 6028-6035. [CrossRef]

17. Galletto, P.; Brevet, P.F.; Girault, H.H.; Antoine, R.; Broyer, M. Enhancement of the Second Harmonic Response by Adsorbates on Gold Colloids: The Effect of Aggregation. J. Phys. Chem. B 1999, 103, 8706-8710. [CrossRef]

18. Mulvaney, P.; Liz-Marzán, L.M.; Giersig, M.; Ung, T. Silica encapsulation of quantum dots and metal clusters. J. Mater. Chem. 2000, 10, 1259-1270. [CrossRef]

19. Chou, D.-W.; Huang, C.-J.; Liu, N.-H. Synthesis of the Small and Uniform Gold Nanoparticles by Electrochemical Technique. J. Electrochem. Soc. 2016, 163, D603-D607. [CrossRef]

20. Huang, C.-J.; Chiu, P.-H.; Wang, Y.-H.; Yang, C.-F. Synthesis of the gold nanodumbbells by electrochemical method. J. Colloid Interface Sci. 2006, 303, 430-436. [CrossRef]

21. Huang, C.-J.; Chiu, P.-H.; Wang, Y.-H.; Yang, C.-F.; Feng, S.-W. Electrochemical formation of crooked gold nanorods and gold networked structures by the additive organic solvent. J. Colloid Interface Sci. 2007, 306, 56-65. [CrossRef]

22. Huang, C.-J.; Wang, Y.-H.; Chiu, P.-H.; Shih, M.-C.; Meen, T.-H. Electrochemical synthesis of gold nanocubes. Mater. Lett. 2006, 60, 1896-1900. [CrossRef]

23. Sze, P.-W.; Lan, W.-H.; Chou, D.-W.; Liu, N.-H.; Feng, S.-W.; Huang, C.-J. The Effect of Ascorbic Acid Using in Electrochemical Method to Synthesize Gold Nanoparticles. J. Nanosci. Nanotechnol. 2017, 17, 5735-5739. [CrossRef]

24. Lagodzinskaya, G.V.; Laptinskaya, T.V.; Kazakov, A.I.; Kurochkina, L.S.; Manelis, G.B. Slow large-scale supramolecular structuring as a cause of kinetic anomalies in the liquid-phase oxidation with nitric acid. Russ. Chem. Bull. 2016, 65, 984-992. [CrossRef]

25. Manelis, G.B.; Lagodzinskaya, G.V.; Kazakov, A.I.; Chernyak, A.V.; Yunda, N.G.; Kurochkina, L.S. Influence of the supramolecular structure of the liquid reaction medium on the kinetics of acetone oxidation with aqueous solutions of nitric acid. Russ. Chem. Bull. 2013, 62, 994-1002. [CrossRef]

26. Rubtsov, Y.I.; Kazakov, A.I.; Sorokina, T.V.; Manelis, G.B. Critical phenomena in acetone oxidation by nitric acid. Russ. Chem. Bull. 2008, 57, 2065-2071. [CrossRef] 